\title{
$\beta$-Amyrin Modulates P38 MAPK and Jnk Pathway to Inhibit Cell Proliferation and Induce ROS-mediated Apoptosis in HeLa Cells
}

\author{
J. ANBURAJ ${ }^{1}$, E. TAMILSELVI* ${ }^{*}$ S. SWAPNA², K. AMUTHAVALLI ${ }^{3}$
}

Department of Biotechnology, Karpagam Academy of Higher Education, Pollachi Main Road, Eachanari Post, Coimbatore-641 021, India, ${ }^{1}$ College of Horticulture, Tea Research Institute, Nanjing Agricultural University, Nanjing, Jiangsu, P. R. China, ${ }^{2}$ Department of Laboratory Services, Hindu Mission Hospital, Tambaram-600 045, ${ }^{3}$ VRR Institute Of Biomedical Science, Chennai-600 056, India

Anburaj et al.: $\beta$-Amyrin induces ROS-mediated apoptosis

\begin{abstract}
It is aimed to investigate the effect of $\beta$-amyrin on p38 mitogen-activated protein kinase and Jun N-terminal kinase pathways and apoptosis in HeLa cells. HeLa treated cells were divided into 6 groups, group IHeLa untreated cells as control, group II- dimethyl sulfoxide serve as vehicle control, group III- cisplatin as standard drug, group IV- $\beta$-amyrin-treated HeLa cells, group V-cells were pretreated with $100 \mu \mathrm{m}$ $\mathrm{N}$-acetyl-L-cystein for 1 hour and then treated with cisplatin and group VI- cells were pretreated with $100 \mu \mathrm{m} N$-acetyl-L-cystein for 1 hour and then treated with $\beta$-amyrin. The antiproliferative effect was measured using the MTT assay. Genotoxic effects were studied using micronucleus assay. Total reactive oxygen species, nitric oxide and caspase 3 level were determined on a spectrofluorimeter and colorimeter. Protein expression was analyzed by immunoblotting. $\beta$-Amyrin (10-200 $\mu \mathrm{m})$ and cisplatin $(0.01-100 \mu \mathrm{m})$ had an inhibitory effect on the proliferation of cancer cells in a dose-dependent manner, with the IC50 values at $100 \mu \mathrm{m}$ and $10 \mu \mathrm{m}$ for $\beta$-amyrin and cisplatin, respectively. Western blot analysis revealed expressions of apoptotic pathway related proteins, Bcl-2, caspase-3, caspase-9, phospho-p38 mitogen-activated protein kinase and phospho-Jun $\mathrm{N}$-terminal kinase, growth arrest and deoxyribonucleic acid-damage-inducible, beta in all groups. Genotoxic effects were observed after treatment with $\beta$-amyrin as well as with cisplatin. It was observed that HeLa cells showed significant elevation of total reactive oxygen species after $\beta$-amyrin treatment. Protein expression analysis showed that the $\beta$-amyrin upregulated phospho-p38 mitogenactivated protein kinase, phospho-Jun $\mathrm{N}$-terminal kinase and growth arrest and deoxyribonucleic aciddamage-inducible, beta on HeLa cells. Increased phospho-Jun N-terminal kinase directly activated caspases and decreased Bcl-2 in HeLa cells. These results indicated that $\beta$-amyrin induced the apoptosis through reactive oxygen species-mediated mechanism by activating p38 mitogen-activated protein kinase and Jun N-terminal kinase through transcriptional factor, GADD45ß. In turn, activated Jun N-terminal kinase directly activated caspase-9 and caspase-3 and destined the HeLa cells to apoptosis.
\end{abstract}

Key words: $\beta$-Amyrin, HeLa, apoptosis, micronucleus, p38MAPK, JNK

Cancer is one of the most critical public health issues and a leading cause of human death worldwide ${ }^{[1,2]}$. Cervical cancer is generally caused by human papilloma virus (HPV) infection is the first prevalent gynecological cancers worldwide ${ }^{[3,4]}$. Recent data indicated that cervical cancer became the second ranked in morbidity and mortality in women after breast cancer $^{[5]}$. Early diagnosis of cervical cancer is curable but metastasis is poor to prognosis. Approximately $50 \%$ of cancer patients die at metastasis stage ${ }^{[6]}$.

*Address for correspondence E-mail: tami24684@gmail.com
HeLa cell line is the one of the most important HPV type 18 infected-cervical cancer cells and widely used in various experimental studies of cervical cancer ${ }^{[7,8]}$. Recent reports have shown that the induction of

\footnotetext{
This is an open access article distributed under the terms of the Creative Commons Attribution-NonCommercial-ShareAlike 3.0 License, which allows others to remix, tweak, and build upon the work non-commercially, as long as the author is credited and the new creations are licensed under the identical terms
} Indian J Pharm Sci 2020;82(3):420-428 
apoptosis is considered as a most promising approach to destroy cancer cells in the field of cancer biology ${ }^{[9,10]}$. Apoptosis is a programmed cell death by which many intracellular events play a crucial role to remove the unwanted cells. Disorders in the apoptosis lead to many diseases including neurodegenerative diseases and autoimmune diseases ${ }^{[1]]}$. Cancer cells stop the apoptosis in order to metastasis but apoptosis mediated cell death eradicate the cancer cell without harming normal cells and without causing inflammatory response. Therefore, apoptosis targeting pathways in the treatment of cancer could be a useful therapeutic approach ${ }^{[12]}$.

Reactive oxygen species (ROS) is secondary metabolites in aerobic metabolism and its low production in the cellular level regulates many signaling pathways including Jun N-terminal kinase (JNK) and p38 mitogenactivated protein kinase (p38 MAPK) pathways. But its overproduction leads to oxidative stress. Apart from controlling the various signaling pathways ROS is also assumed to induce apoptosis pathways by promoting transcription of proapoptotic genes ${ }^{[13]}$. Many anticancer agents including paclitaxel and tamoxifen are believed to kill cancer cells by apoptosis pathways. However, these compounds pose adverse side effects during cancer treatment, therefore it's necessary to develop new drugs with little side effects or without side effects for managing this disease. It is strongly believed that plants are considered as an attractive natural sources with antitumor, antioxidant and antiinflammatory activities. More than $60 \%$ of currently used anticancer drugs are derived from plants and marine sources and also many scientific studies have demonstrated the potentiality of plant-derived compounds against many cancers including cervical cancer ${ }^{[13,14]}$.

These plant compounds eliminate cancer cells using different channels but eventually all these compounds eradicate cancer cells via apoptosis and thus it is important to discover more specific targeted apoptosis inducing plant-derived compounds. Several studies reported that plant derived compounds selectively eliminate cancer cells through ROS metabolism ${ }^{[15,16]}$. As ROS is a major attributed factor of regulating the apoptosis pathways and also involved in destroying cancer cells, it is important to unravel the ROSmediated apoptosis mechanism in the cancer cells.

Triterpene compounds are well known for antiinflammatory, antiapoptotic activity in various cell lines. Many in vitro and in vivo studies have shown that oleanolic acid and other oleanane triterpenoids modulate intracellular signaling pathway and exert antitumor activity against various cancer cell lines ${ }^{[17]}$. $\beta$-Amyrin is a pentacyclic triterpenes found in many plants and barks of trees such as Protium kleinii, Protium hepta phyllum and Moldenhawera Nutans ${ }^{[18-20]}$. Previous studies showed that $\beta$-amyrin possess different pharmacological activities such as antiinflammatory, antifibrotic and antidiabetic activities. Several studies reported that pentacyclic triterpenes such as ursolic acid and oleanolic acid which are structurally similar to $\beta$-amyrin can suppress the cancer development and metastasis through the inhibition of angiogenesis ${ }^{[21,22]}$. However, no studies analyzed the effect of $\beta$-amyrin on ROS mediated signaling that induce apoptosis. Therefore, we investigated the effect of $\beta$-amyrin role in controlling cervical cancer through ROS-mediated apoptosis.

\section{MATERIALS AND METHODS}

HeLa cells were obtained from National Center for Cell Science (Pune, India) was maintained and grown in a humidified incubator at $37^{\circ}$ with $5 \% \mathrm{CO}_{2}$. Cells were grown as a monolayer in plastic tissue culture flasks in Dulbecco's modified Eagle's medium (DMEM) Gibco, USA). The medium was supplemented with $10 \%$ fetal bovine serum (FBS) and antibiotics, penicillin $50 \mathrm{IU} / \mathrm{ml}$, streptomycin $3.5 \mu \mathrm{g} / \mathrm{ml}$ and gentamycin $2.5 \mu \mathrm{g} / \mathrm{ml}$. All these were procured from Gibco, Grand Island, NY, USA. Triton X-100 (Cat No. 93443), $0.1 \mathrm{mg} / \mathrm{ml}$ RNase (R4642) and $40 \mu \mathrm{g} / \mathrm{ml}$ propidium iodide (PI, P4170) were all procured from SigmaAldrich.

\section{Cell viability assay:}

Cells were seeded in 96-well plates at a density of $5 \times 10^{3}$ cells/well in $200 \mu \mathrm{l}$ DMEM containing $10 \%$ FBS overnight. Non-adherent cells were removed by gentle washing after $24 \mathrm{~h}$. Cells were replaced with serum-free medium with varying concentrations of $\beta$-amyrin $(10-200 \mu \mathrm{m})$ and cisplatin $(0.01-100 \mu \mathrm{m})$. A negative control containing serum-free medium with dimethyl sulfoxide (DMSO) was also evaluated. After $72 \mathrm{~h}$ of treatment, the plates were incubated with $20 \mu \mathrm{l}$ 3-(4,5-dimethylthiazol-2-yl)-2,5-diphenyltetrazolium bromide (MTT) solution $(5 \mathrm{mg} / \mathrm{ml})$ for $3 \mathrm{~h}$ at $37^{\circ}$. The formazan was dissolved in $150 \mu \mathrm{l} /$ well DMSO and the absorbance was detected at $590 \mathrm{~nm}$ using a microplate reader (Bio-Rad, USA). Cell viability was expressed as percentage of untreated cells, which served as the negative control group and was designated as $100 \%$. The results were expressed in percentage of the negative control. The median inhibitory concentration 
$\left(\mathrm{IC}_{50}\right.$, defined as the drug concentration at which cell growth was inhibited by $50 \%$ ) was assessed from the dose-response curves ${ }^{[23]}$.

\section{Experimental groups:}

The experiment was divided into six groups, group I- HeLa untreated cells served as control, group II- DMSO-treated HeLa cells served as vehicle control, group III- $10 \mu \mathrm{m}$ cisplatin-treated HeLa cells, group IV- $100 \mu \mathrm{m} \beta$-amyrin-treated HeLa cells, group $\mathrm{V}$ - cells were pretreated with $100 \mu \mathrm{m} \mathrm{N}$-acetyl-L-cystein (NAC) for $1 \mathrm{~h}$ and then treated with $10 \mu \mathrm{m}$ of cisplatin and group VI- cells were pretreated with $100 \mu \mathrm{m}$ NAC for $1 \mathrm{~h}$ and then treated with $100 \mu \mathrm{m}$ of $\beta$-amyrin.

\section{Micronuclei assay by flow cytometry:}

Flow cytometry provides a convenient research tool to determine the frequency of micronuclei. The in vitro flow cytometry-based micronucleus (MN) assay ${ }^{[24]}$ provides an alternative to the traditional MN genotoxicity assay that has potential use as a rapid screening assay.

\section{Sample preparation for MN analysis:}

Cells were seeded at $1 \times 10^{5}$ in $60 \mathrm{~mm}$ dishes. After removing non-adherent cells by gentle wash, the cells were treated with $10 \mu \mathrm{m}$ cisplatin and $100 \mu \mathrm{m}$ $\beta$-amyrin, respectively. To arrest the cells at cytokinesis stage at $37^{\circ}$, cytochalasin-B $(3 \mu \mathrm{g} / \mathrm{ml})$ was added. The cells were harvested and fixed by adding ice-cold $70 \%$ ethanol after $72 \mathrm{~h}$. For the experiment, the samples were centrifuged for $10 \mathrm{~min}$ at $1500 \mathrm{rpm}$. After discarding the supernatant, the pellets were resuspended in PBS until ethanol removed completely. Following this, the cells were then resuspended in PBS $(500 \mu \mathrm{l})$ containing $\mathrm{NaCl}(584 \mathrm{mg} / \mathrm{l})$, sodium citrate $(1000 \mathrm{mg} / \mathrm{l}), 0.5 \%$ Triton X-100, $0.1 \mathrm{mg} / \mathrm{ml} \mathrm{RNase}$ and $40 \mu \mathrm{g} / \mathrm{ml} \mathrm{PI} \mathrm{in}$ a dark room. Triton X-100 and RNase were added to permeable the cell membrane and eliminate RNA. Samples were protected from light and allowed to equilibrate to room temperature before flow cytometric analysis was performed. After $45 \mathrm{~min}$ incubation at $37^{\circ}$, the cells were transferred to a FCM tube and analyzed on a flow cytometer (FACS Calibur, Becton Dickinson Biosciences), equipped with an air cooled argon laser providing $15 \mathrm{~mW}$ at $488 \mathrm{~nm}$ with standard filter setup and 100000 events were collected.

Bivariate dot plots displayed on logarithmic scales were used to register signals of DNA (FSC vs. FL2-H or SSC vs. FL2-H). Nuclei and MN were discriminated from non-specific debris using the electronic gates. The percentage of MN frequency was calculated based on the acquisition of 100000 events using the formula, $\%$ of $\mathrm{MN}=($ total $\mathrm{MN} /$ total $\mathrm{N}) \times 100, \mathrm{MN}$ indicates total micronuclei and $\mathrm{N}$ indicates total nuclei.

\section{Determination of total ROS and nitric oxide (NO):}

Cells were washed with PBS and loaded with CMH2DCFDA for $15 \mathrm{~min}$. Fluorescence of the H2DCFDA was read at $480 \mathrm{~nm}$ excitation $/ 520 \mathrm{~nm}$ emission in a Hitachi F2000 spectrofluorimeter. The results were expressed as $\mathrm{nM} / \mathrm{mg}$ of protein. Nitrite $\left(\mathrm{NO}_{2}\right)$ and nitrate $\left(\mathrm{NO}_{3}\right)$ in HeLa cells were measured using $\mathrm{NO}$ assay kit (ab65328, Abcam) according to manufacturer protocol.

\section{Determination of caspase- 3 for colorimetric assay:}

Caspase-3 activity was determined using a colorimetric method in which the presence of caspase-3 lysate produces p-nitroaniline, which generates a yellow color. Cells plated in a sterile 24-well plate at a concentration of $1 \times 10^{5}$ cells $/ \mathrm{ml}$ and were incubated at $37^{\circ}$ in $5 \% \mathrm{CO}_{2}$ for $72 \mathrm{~h}$. After this period, the determination of caspase-3 was performed according to the manufacturer's specification (Sigma-Aldrich, St. Louis, MO) using an ELISA reader. The analyses were the average of three replicates, and the results were expressed in $\Delta \mathrm{mOD} 405 \mathrm{~nm} / \mathrm{min}^{[25]}$.

\section{Western blotting:}

Cells were seeded in 24-well plates at a density of $5 \times 10^{4}$ cells/well in $1 \mathrm{ml}$ of medium containing $10 \% \mathrm{FBS}$ overnight. Non-adherent cells were removed by gentle washing after $24 \mathrm{~h}$. Cells were lysed by the addition of cold RIPA buffer (150 mM NaCl, $50 \mathrm{mM}$ Tris HCL, $0.1 \%$ SDS, $1 \%$ Triton X-100, 1 mM PMSF, 2 mM NaF, $\mathrm{Na}_{3} \mathrm{VO}_{4}, \beta$-glycerophosphate and $2 \mathrm{mM}$ EDTA, and fresh protease inhibitor cocktail (Cat No. P8340, Sigma Aldrich), and the cell lysate was centrifuged at 14000 rpm at $4^{\circ}$ for $20 \mathrm{~min}$. The supernatant was harvested and analyzed for protein content using the BCA method (Cat No.23227, Pierce, USA). Protein was denatured in sample buffer, then separated on $12 \%$ SDS-PAGE, and transferred to polyvinylidene difluoride membranes (semidry transblot system). The blots were blocked for $1 \mathrm{~h}$ at room temperature with Tris-buffered saline (TBS, $50 \mathrm{mM}$ Tris- $\mathrm{HCl}, \mathrm{pH} 7.5,150 \mathrm{mM} \mathrm{NaCl}$ ) containing $5 \%$ non-fat milk. The blots were washed three times with TBST $(50 \mathrm{mM}$ Tris- $\mathrm{HCl}, \mathrm{pH} 7.5$, $150 \mathrm{mM} \mathrm{NaCl}$, and $0.02 \%$ Tween 20) and incubated with Bcl-2, caspase-3, caspase-9, phospho-p38 MAPK, 
and phospho-JNK, GADD45 $\beta$ (Santa Cruz, CA, 1:1000 dilutions) antibodies at $4^{\circ}$ overnight. The blots were incubated for $1 \mathrm{~h}$ at room temperature with secondary antibody (1:5000 dilutions) and detected by ECL detection reagent. To ensure that an equal amount of sample protein was applied for electrophoresis, $\beta$-actin was used as an internal control. Densitometric analysis was done using Image J software.

\section{Statistical analysis:}

Data were presented as mean $\pm \mathrm{SEM}$. Each value is the mean of at least three separate experiments. Statistical evaluation was performed using an unpaired Student's $\mathrm{t}$ test. $\mathrm{p}$ values $<0.05$ were considered to be statistically significant. Data were analyzed using SPSS software (version 16.0).

\section{RESULTS AND DISCUSSION}

The effects of $\beta$-amyrin and cisplatin on the proliferation of HeLa cells were examined. Fig. $1 \mathrm{~A}$ and B showed the percentage of viable cells obtained in the MTT assay with varying concentrations of $\beta$-amyrin $(5-200 \mu \mathrm{m})$ and cisplatin $(0.01-100 \mu \mathrm{m})$. The significantly dose-dependent reduction on the cell proliferation was observed in cells treated with both $\beta$-amyrin and cisplatin. After $72 \mathrm{~h}$ of incubation, the IC50 values for $\beta$-amyrin and cisplatin were $100 \mu \mathrm{m}$ and $10 \mu \mathrm{m}$, respectively. Interestingly cell viability slightly but not significantly increased with increasing $\beta$-amyrin concentration. Moreover, there is a timeand dose-dependent increase in cell death of HeLa cells, reaching approximately $60 \%$ of cells after $36 \mathrm{~h}$ of treatment with $100 \mu \mathrm{m} \beta$-amyrin. The doses of 150 and $200 \mu \mathrm{m}$ showed an increased cell death of approximately $90 \%$ after $36 \mathrm{~h}$ treatment (fig. 1C).

The effect of $\beta$-amyrin on total ROS level in HeLa was determined using spectrofluorimetric method (fig. 2A). It was observed that HeLa cells showed significant elevation of total ROS after cisplatin and $\beta$-amyrin treatment $(p<0.001)$ compared to control and vehicle groups, but there is no significant differences were observed between cisplatin and $\beta$-amyrin-treated HeLa cells. $\beta$-amyrin ROS elevating action was further confirmed by using NAC. NAC pretreatment to cisplatin and $\beta$-amyrin group showed significant $(p<0.001)$ decrease in ROS level compared to cisplatin and $\beta$-amyrin-treated HeLa cells. However pretreatment of cells with $3 \mathrm{mM}$ of NAC reversed ROS accumulation close to the untreated control levels. This indicated that ROS could be the major factor for the drug-induced
(A)

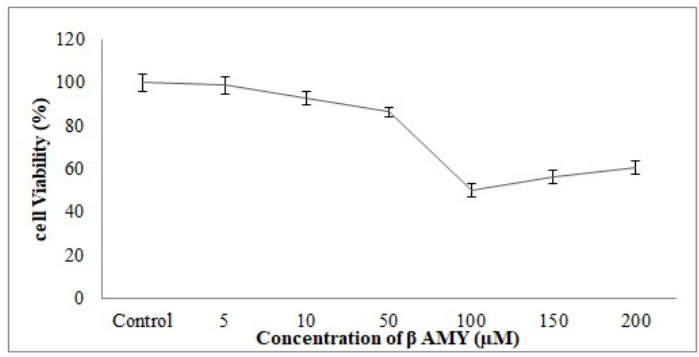

(B)
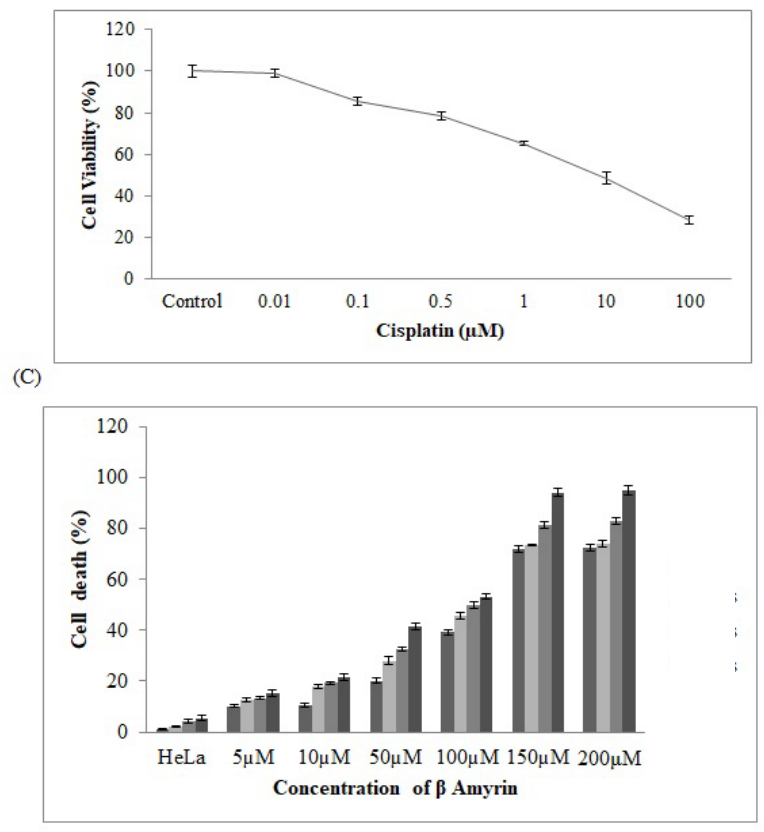

Fig. 1: Antiproliferative effect of Cisplatin and $\beta$-amyrin
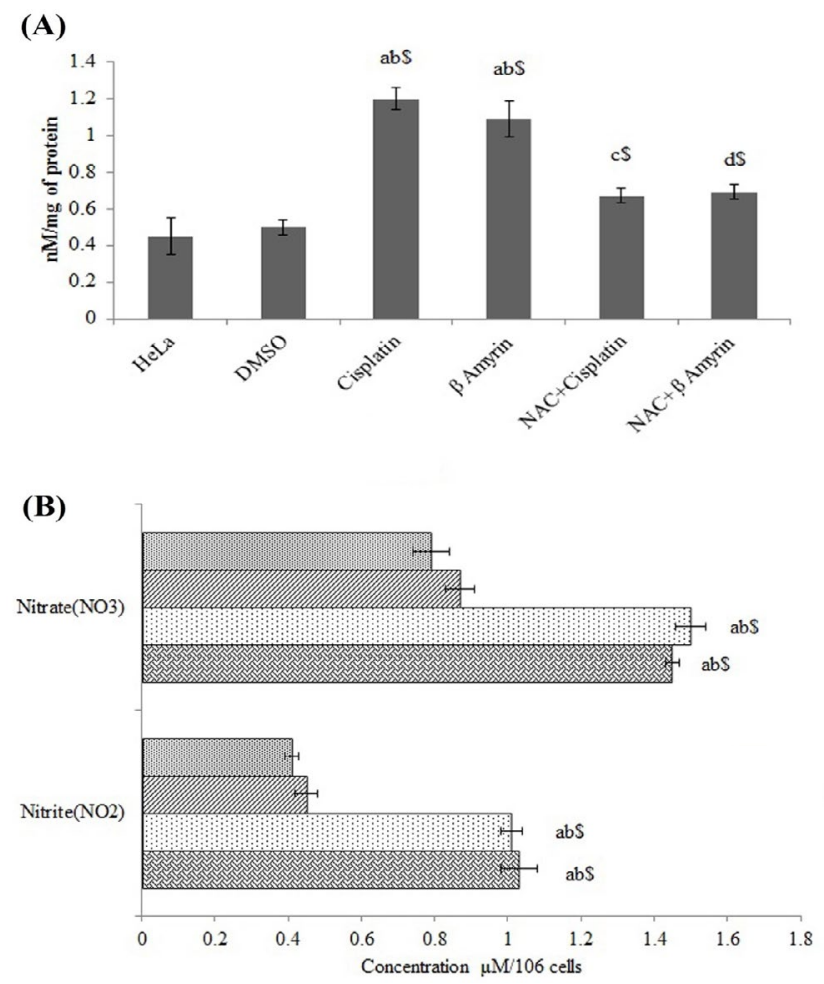

Fig. 2: Effect of $\beta$-amyrin on total ROS and NO level in HeLa cells with references to NAC treatment 
apoptosis. Fig. 2B shows the effect of $\beta$-amyrin on nitrate-nitrite levels in HeLa cells. Results showed that levels of nitrite-nitrate were significantly higher in control groups and their levels decreased significantly $(\mathrm{p}<0.001)$ after cisplatin and $\beta$-amyrin treatment.

Fig. 3 showed the Gating image of the MN frequencies. Baseline micronuclei frequency obtained in untreated control cells were $0.86 \pm 0.09$. There were no significant differences between the DMSO and the control group. There was a significant increase $(p<0.001)$ in $\mathrm{MN}$ frequencies of cisplatin-treated cells when compared to both HeLa cells and DMSO+HeLa cells groups. A significant $(\mathrm{p}<0.001)$ frequency of $\mathrm{MN}$ was obtained in cells treated with $\beta$-amyrin $3.25 \pm 0.53$ when compared to both HeLa cells and DMSO+HeLa cells groups. There is no significant changes observed between cisplatin and $\beta$-amyrin-treated HeLa cells (fig. 4).

The activity of cleaved caspase- 3 in $\beta$-amyrin and cisplatin-treated $\mathrm{HeLa}$ cells were determined colorimetrically at $\Delta \mathrm{mnOD} 405 \mathrm{~nm} / \mathrm{min}$ (fig. 5). The
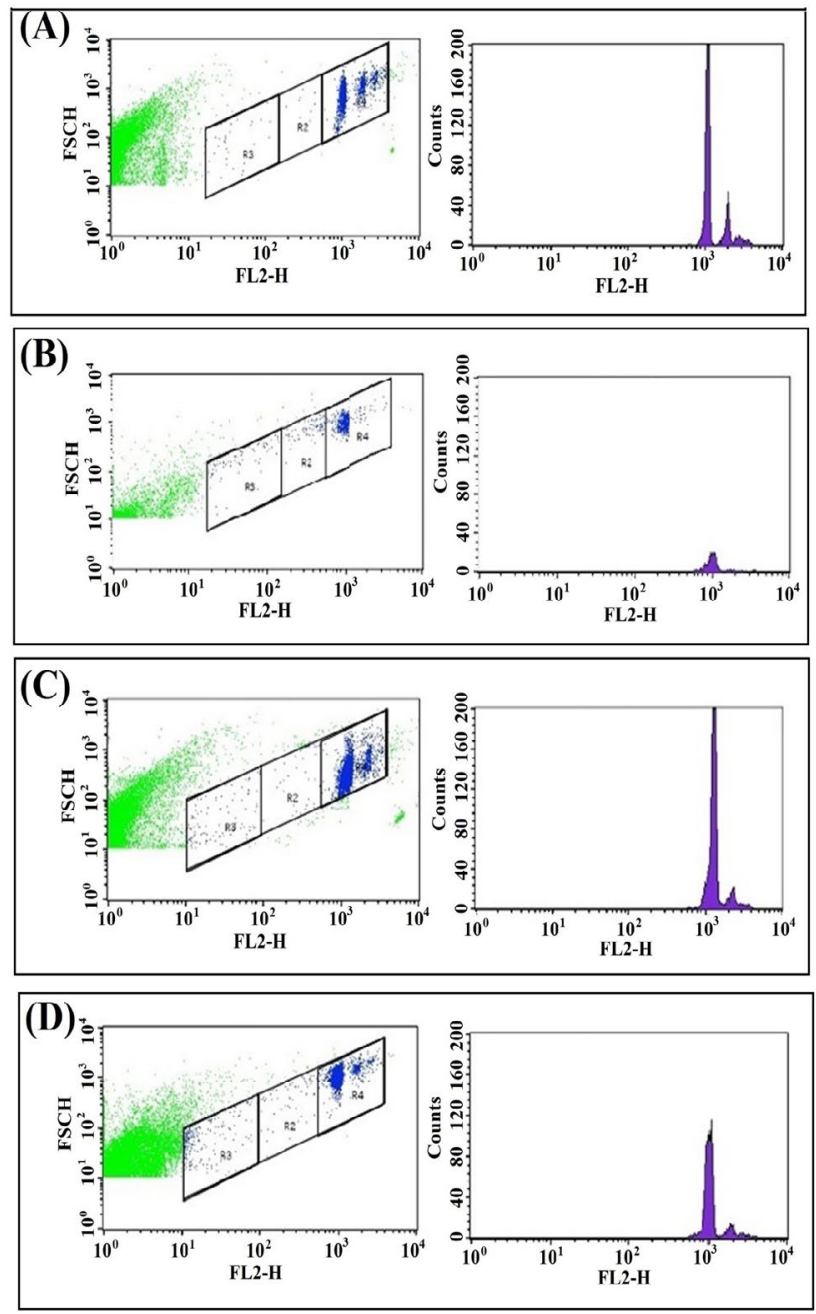

Fig. 3: Genotoxicity effect of cisplatin and $\beta$-amyrin treated HeLa cells by micronucleus assay

May-June 2020

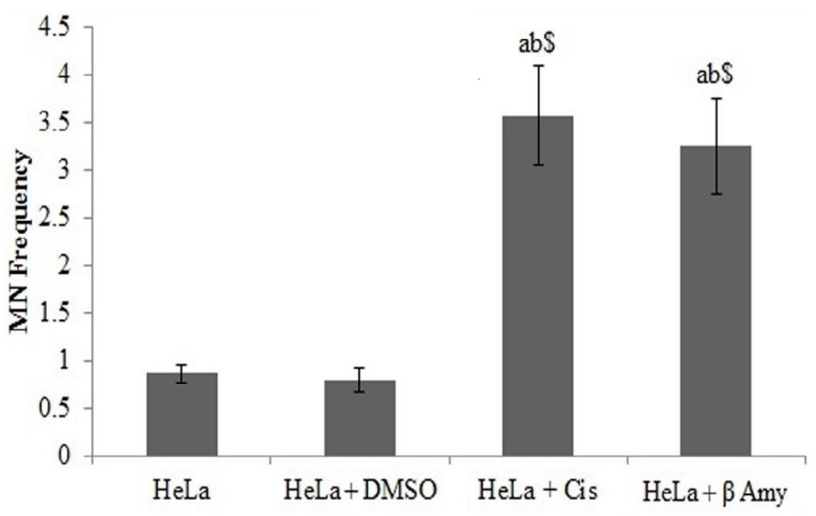

Fig. 4: Graphical representation of the micronuclei frequencies

activity of caspase- 3 were observed to be decreased in controls groups, whereas $\beta$-amyrin and cisplatin treatment significantly $(\mathrm{p}<0.001)$ increased the caspase- 3 activity compared to both control groups.

The ROS-mediated apoptosis on HeLa cells was induced by $\beta$-amyrin through activating various proteins involved in p38 MAPK pathway in order to cause programmed cell death of cancer cells. The expressions of various proteins like phospho-p38 MAPK, phosphoJNK, GADD45 $\beta$, Bcl-2, caspase-9 and caspase 3 were done by using immunoblotting (fig. 6A). The densities of bands corresponding to all these proteins were normalized on the basis of $\beta$ actin and analyzed relative to that of the normal control group, as shown in fig. $6 \mathrm{~B}$.

The phosphorylated kinases like p38 MAPK, JNK and transcription factor GADD $45 \beta$ involved in the ROSmediated apoptosis expression were downregulated in untreated HeLa cells as well as DMSO-treated HeLa cells, no significant differences were found between these groups. HeLa cells treated with $\beta$-amyrin and cisplatin showed significant $(\mathrm{p}<0.001)$ upregulation of all proteins compared to both control groups but did not show any significant differences among drug-treated cells.

As observed earlier, the activity of caspase- 3 was further confirmed by immunoblotting. Expression of apoptotic proteins, caspase- 9 and caspase- 3 decreased in the untreated HeLa cells, DMSO-treated HeLa cells, while in cisplatin- and $\beta$-amyrin-treated cells the expression was significantly $(\mathrm{p}<0.001)$ increased compared to both control groups. But there is no significant difference was observed between cisplatin- and $\beta$-amyrin-treated HeLa cells.

Expression of antiapoptotic protein Bcl-2 in HeLa cells was analysed using the Western blot. Bcl-2 expression was upregulated in HeLa cells as well as in DMSOtreated cells. Treatment of HeLa cells with $\beta$-amyrin 


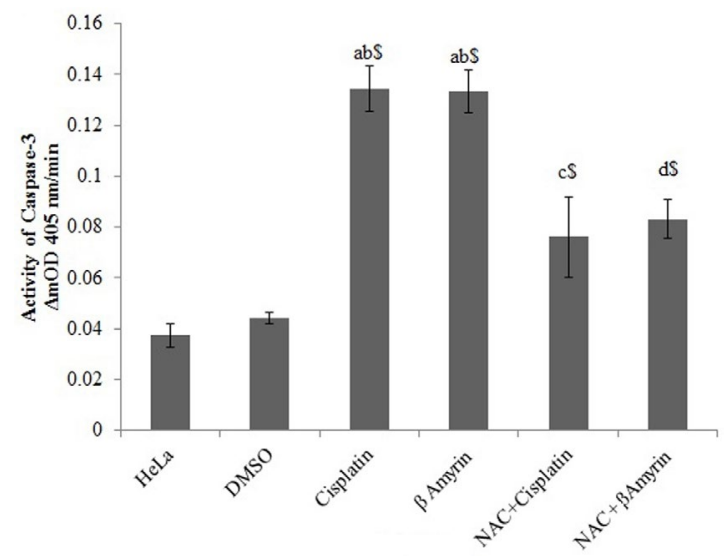

Fig. 5: Colorimetric analysis of caspase-3 activity on HeLa cells before and after $\beta$-amyrin with references to NAC treatment

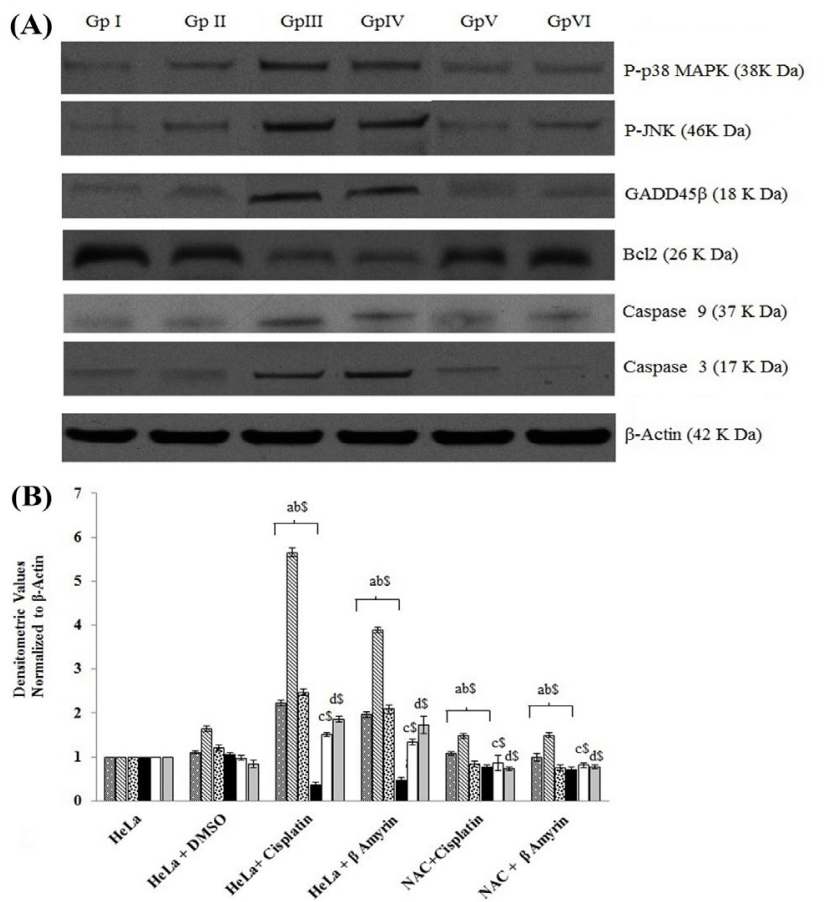

Fig. 6: Immunoblotting analysis of ROS induced various proteins on $\boldsymbol{\beta}$-amyrin-treated HeLa cells

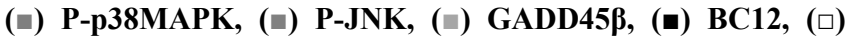
caspase 9, ( ) caspase 3

and cisplatin significantly downregulated Bcl-2 protein expression, when compared to the normal control group. Also, Bcl-2 protein expression in cisplatintreated HeLa cells showed no significant differences compared to $\beta$-amyrin-treated HeLa cells.

$\beta$-Amyrin impact on ROS-induced apoptosis is further confirmed by the NAC pretreated group. p38, JNK, GADD $45 \beta$, caspase-9, caspase-3 and Bcl-2 showed no significant changes in NAC-pretreated cisplatin and $\beta$-amyrin groups compared to HeLa cells and DMSO + HeLa cells.

Metastasis and proliferation are the main pathological factors of cancer. It mainly occurs due to abnormality in apoptotic molecular machinery, which leads to survival of metastatic cells in cancer. To minimize or prevent the proliferation of cancer cells, the therapeutic agents are designed to induce various apoptosis signal transduction to destroy the cancer cells. Many reports have shown antiproliferative properties of triterpenes against multiple tumor cells. In fact, to improve their activities, synthetic analogs of oleanolic acid have been developed and are under clinical evaluation as antitumor agents for hematologic malignancies ${ }^{[26-29]}$. Based on the previous evidences, chosen $\beta$-amyrin, a natural triterpene with oleanonic structure was chosen to study on HeLa cells.

The appearance of $\mathrm{MN}$ is closely linked to DNA damage process and genome instability. Monitoring the frequency of micronuclei is therefore widely used to assess the environmental or endogenous stresses that damage the genome ${ }^{[30]}$. The increased formation of micronuclei is usually an indication of increased DNA damage or mutation. It is characteristically found in all types of cancer cells. Increased frequency of micronuclei in the cisplatin- and $\beta$-amyrin-treated groups was observed. Cisplatin exhibited growth inhibition and cytotoxicity in a dose-dependent manner, with an $\mathrm{IC}_{50}$ value of $10 \mu \mathrm{M}$ on HeLa cells. Cisplatin forms highly reactive, charged, platinum complexes which bind to nucleophilic groups such as GC-rich sites in DNA, inducing intra and inter strand DNA cross-links, as well as DNA-protein cross-links. These cross-links result in cell growth inhibition and apoptosis. Studies reported that the inhibition of transcription and replication due to cisplatin-induced DNA lesions and the subsequent generation of DNA strand breaks activate the ATR and ATM kinases as well as the p38 MAPK/MK2 pathway ${ }^{[11,32]}$. Present study proved for the first time that $\beta$-amyrin is a potent clastogenic, which produced a large number of DNA lesions. Increased ROS production in HeLa cells may occur due to the prooxidative shift in the redox state and impaired glucose clearance in mitochondria, which directly causes mitochondrial oxidative stress. Prooxidative shift observed in all cancers is mainly mediated by an increased availability of mitochondrial energy substrate and inflammatory oxidative conditions. Chronic inflammatory tissue contains large amounts of $\mathrm{NO}$ and derivatives ROS. NO and ROS generally cause direct and indirect damage to DNA and other genetic material ${ }^{[33]}$. The significant balance and interaction between NO and ROS has a foremost role in the etiology of a tumor ${ }^{[34]}$. All these conditions involved with pathological changes are indicative of a dysregulation of signal cascades or gene 
expression that leads to increase ROS production in cells $^{[35]}$.

In this study, increased total ROS level and NO level were found in HeLa cells and DMSO-treated HeLa cells. Cisplatin and $\beta$-amyrin treatment on HeLa cells increased total ROS further and decreased NO level, which was confirmed by NAC pretreatment to these cells. The increased ROS and NO in HeLa cells might be ROS derived from NO•, which are released from inflammatory cells and act on neighboring dividing cells leading to somatic mutations in critical cancercausing genes. NO produced by inducible nitric oxide synthase in solid tumors has been implicated in enhanced vascular permeability and increased tumor blood flow and hence sustained tumor growth ${ }^{[35]}$. Chronic inflammation has also been considered to be a risk factor for a variety of human malignant tumors, particularly cervical carcinoma. Even though increased ROS production were observed in all types of cancer cells still these cancer cells does not undergone ROSmediated apoptosis, this might be due to the increased NO level. Generally, increased NO have the direct opposing effect on ROS-mediated apoptosis by inhibiting heat shock protein (HSP $)^{[36,37]}$. Recent studies using triterpenoids supported the results that $\beta$-amyrin increased further total ROS levels in HeLa cells ${ }^{[38-40]}$. As stated earlier, $\beta$-amyrin, a triterpenes with oleanolic compound structure, which increased ROS production further and induces ROS-mediated apoptosis. This action might occur due to its antiinflammatory property. This property cause's decreased production of inflammatory mediators thereby reducing the NO level which might lead to activate HSP thereby induces ROS-mediated apoptosis of HeLa cells. Apart from controlling inflammatory oxidative condition, $\beta$-amyrin also causes mitochondrial oxidative stress to induce ROS-mediated apoptosis by activating p38 and JNK signaling pathway and these results were discussed further in this study. JNK and p38 MAPK family members function in a cell context-specific and cell type-specific manner to integrate signals that affect proliferation, differentiation, survival and migration. Consistent with the importance of these events in tumorigenesis, JNK and p38 MAPK signalling is associated with cancers in humans and mice ${ }^{[41]}$. In the present study, $\beta$-amyrin was found to activate/ phosphorylate p38 MAPK, JNK signaling in HeLa, which in turn activated the transcription factor GADD $\beta 45$ and $\beta$-amyrin also activated $\mathrm{p} 38$ and JNK pathway to induce apoptosis of HeLa cells. Many studies have shown that these two pathways induced apoptosis in cancer cells ${ }^{[22,43]}$. Several factors are involved in the activation of these pathways. ROS is considered as a one of the most important factor that activate these signaling pathway to induce cancer cell death ${ }^{[44]}$. Many synthetic and plant-derived triterpenoids have potential anticancer activities ${ }^{[45-49]}$. Recent studies showed that triterpenoid mainly induced apoptosis by targeting ROS-induced activation of JNK and p38 MAPK, which further activate caspases ${ }^{[50]}$. Recent reports have provided evidence that JNK activated caspases ${ }^{[51]}$. Consistent with these findings, in the present study $\beta$-amyrin activated $\mathrm{p} 38 \mathrm{MAPK}$ and JNK pathways in a caspase-dependent manner. Activation of transcription factor GADD $45 \beta$ by JNK further leads to cleave the procaspase 9 and increased caspase 9 and caspase 3 expressions to induce ROS-mediated apoptosis. Activation of these signaling pathways by $\beta$-amyrin not only cleaved the caspase 3 but also activated antiapoptotic protein Bcl-2 by phosphorylation. Several studies have reported that the antiapoptotic function of Bcl-2 depended on its phosphorylation ${ }^{[52]}$. p38 MAPK and JNK are involved in phosphorylation of Bcl-2, resulting in increased apoptosis. Stress kinase p38 was shown to play a proapoptotic role after various insults and was identified as one of kinases able to directly phosphorylate $\mathrm{Bcl}-2^{[53]}$. Antiapoptotic function of Bcl-2 has been disturbed due to its phosphorylation in the cells treated with taxol or other anticancer agents ${ }^{[54]}$. Consistent with these findings, it was found that $\beta$-amyrin and cisplatin treatment decreased the levels of Bcl-2 in HeLa cells.

In conclusion, ROS play an important role in $\beta$-amyrininduced apoptosis in human cervical adenocarcinoma (HeLa) cell line. The mechanism by which $\beta$-amyrin induced apoptosis involved the following steps. Chronic inflammation and mitochondrial oxidative stress induce rapid generation of ROS, which is required for subsequent activation of apoptosis by $\beta$-amyrin. ROS generation by $\beta$-amyrin occurs mainly in the mitochondria. Apoptosis induced by $\beta$-amyrin is mediated through the activation of $\mathrm{p} 38$, JNK and activated GADD45 $\beta$, which in turn activates mitochondrion-dependent caspase activation pathway, which is negatively regulated by the antiapoptotic Bcl2 protein.

\section{Acknowledgements:}

We acknowledge Karpagam Academy of Higher Education and VRR Institute of biomedical science for 
their support to do this project. Also we would like to acknowledge all our staffs and team mates who kindly support us to complete this project work successfully.

\section{Conflict of Interest:}

No conflict of interest between any of the authors.

\section{REFERENCES}

1. Senwar KR, Reddy TS, Thummuri D, Sharma P, Naidu VG, Srinivasulu G, et al. Design, synthesis and apoptosis inducing effect of novel (Z)-3-(3'-methoxy-4'-(2-amino-2-oxoethoxy)benzylidene) indolin-2-ones as potential antitumour agents. Eur J Med Chem 2016;118:34-46.

2. Weir HK, Anderson RN, Coleman King SM, Soman A, Thompson TD, Hong Y, et al. Heart disease and cancer deaths - trends and projections in the United States, 1969-2020. Prev Chronic Dis 2016;13:E157.

3. Hutchinson DJ, Klein KC. Human papillomavirus disease and vaccines. Am J Health Syst Pharm 2008;65:2105-12.

4. Torre LA, Bray F, Siegel RL, Ferlay J, Lortet-Tieulent J, Jemal A. Global cancer statistics 2012. CA Cancer J Clin 2012;65:87108.

5. World Health Organization (2014). Cancer country profiles.

6. Wright TC, Kuhn L. Alternative approaches to cervical cancer screening for developing countries. Best Pract Res Clin Obstet Gynaecol 2012;26(2):197-208.

7. Scheffner M, Munger K, Byrne JC, Howley PM. The state of the p53 and retinoblastoma genes in human cervical carcinoma cell lines. Proc Natl Acad Sci USA 1991;88:5523-7.

8. Denise M. Watson. Cancer killed Henrietta Lacks-then made her immortal. Virginian-Pilot 2010;1:12-4.

9. Franke TF, Hornik CP, Segev L, Shostak GA, Sugimoto C. PI3K/Akt and apoptosis: size matters. Oncogene 2003;22(56):8983-98.

10. Fresno Vara JA, Casado E, de Castro J, Cejas P, Belda-Iniesta C, González-Barón M. PI3K/Akt signalling pathway and cancer. Cancer Treat Rev 2004;30(2):193-204.

11. Fuchs Y, Steller H. Programmed cell death in animal development and disease. Cell 2011;147(4):742-58.

12. Elmore S. Apoptosis: a review of programmed cell death. Toxicol Pathol 2007;35(4):495-516.

13. Aruoma OI, Sun B, Fujii H, Neergheen VS, Bahorun T, Kang KS, Sung MK. Low molecular proanthocyanidin dietary biofactor Oligonol: its modulation of oxidative stress, bioefficacy, neuroprotection, food application and chemoprevention potentials. Biofactors 2006;27(1-4):245-65.

14. Koppikar SJ, Choudhari AS, Suryavanshi SA, Kumari S, Chattopadhyay S, Kaul-Ghanekar R. Aqueous cinnamon extract (ACE-c) from the bark of Cinnamomum cassia causes apoptosis in human cervical cancer cell line ( $\mathrm{SiHa})$ through loss of mitochondrial membrane potential. BMC Cancer 2010;10:210.

15. Khan M, Li T, Ahmad Khan MK, Rasul A, Nawaz F, Sun $\mathrm{M}$, et al. Alantolactone induces apoptosis in HepG2 cells through GSH depletion, inhibition of STAT3 activation, and mitochondrial dysfunction. Biomed Res Int 2013;2013:719858.

16. Khan $\mathrm{M}$, Yi F, Rasul A, Li $\mathrm{T}$, Wang $\mathrm{N}$, Gao $\mathrm{H}$, et al. Alantolactone induces apoptosis in glioblastoma cells via GSH depletion, ROS generation, and mitochondrial dysfunction. IUBMB Life 2012;64(9):783-94.
17. do Vale AE, David JM, Brandão HN, David JP. A new flavonol glycoside derivative from leaves of Moldenhawera nutans. $\mathrm{Z}$ Naturforsch C 2005;60(1-2):45-9.

18. Oliveira FA, Chaves MH, Almeida FR, Lima RC Jr, Silva RM, Maia JL, et al. Protective effect of alpha- and beta-amyrin, a triterpene mixture from Protium heptaphyllum (Aubl.) March. trunk wood resin, against acetaminophen-induced liver injury in mice. J Ethnopharmacol 2005;98(1-2):103-8.

19. Otuki MF, Vieira-Lima F, Malheiros A, Yunes RA, Calixto JB. Topical antiinflammatory effects of the ether extract from Protium kleinii and alpha-amyrin pentacyclic triterpene. Eur J Pharmacol 2005;507(1-3):253-9.

20. Sohn KH, Lee HY, Chung HY, Young HS, Yi SY, Kim KW. Anti-angiogenic activity of triterpene acids. Cancer Lett 1995;94(2):213-8.

21. Lin CC, Huang CY, Mong MC, Chan CY, Yin MC. Antiangiogenic potential of three triterpenic acids in human liver cancer cells. J Agric Food Chem 2011;59(2):755-62.

22. Saraswati S, Agrawal SS, Alhaider AA. Ursolic acid inhibits tumor angiogenesis and induces apoptosis through mitochondrial-dependent pathway in Ehrlich ascites carcinoma tumor. Chem Biol Interact 2013;206(2):153-65.

23. Mosmann T. Rapid colorimetric assay for cellular growth and survival: application to proliferation and cytotoxicity assays. J Immunol Methods1983;65(1-2):55-63.

24. Nüsse M, Beisker W, Kramer J, Miller BM, Schreiber GA, Viaggi S, Weller EM, Wessels JM. Measurement of micronuclei by flow cytometry. Methods Cell Biol 1994;42(Pt B):149-158.

25. Posmantur R, Wang KK, Gilbertsen RB. Caspase-3-like activity is necessary for IL-2 release in activated Jurkat T-cells. Exp Cell Res 1998;244(1):302-9.

26. Hsu HY, Yang JJ, Lin CC. Effects of oleanolic acid and ursolic acid on inhibiting tumor growth and enhancing the recovery of hematopoietic system postirradiation in mice. Cancer Lett 1997;111(1-2):7-13.

27. Ukiya M, Akihisa T, Tokuda H, Suzuki H, Mukainaka T, Ichiishi E, et al. Constituents of Compositae plants III. Antitumor promoting effects and cytotoxic activity against human cancer cell lines of triterpene diols and triols from edible chrysanthemum flowers. Cancer Lett 2002;177(1):7-12.

28. Juan ME, Wenzel U, Ruiz-Gutierrez V, Daniel H, Planas JM. Olive fruit extracts inhibit proliferation and induce apoptosis in HT-29 human colon cancer cells. J Nutr 2006;136(10):2553-7.

29. Reyes FJ, Centelles JJ, Lupiáñez JA, Cascante M. (2Alpha,3beta)-2,3-dihydroxyolean-12-en-28-oic acid, a new natural triterpene from Olea europea, induces caspase dependent apoptosis selectively in colon adenocarcinoma cells. FEBS Lett 2006;580(27):6302-10.

30. Fenech M, Kirsch-Volders M, Natarajan AT, Surralles J, Crott JW, Parry J, et al. Molecular mechanisms of micronucleus, nucleoplasmic bridge and nuclear bud formation in mammalian and human cells. Mutagenesis 2011;26(1):125-32.

31. Bartek J, Lukas J. DNA damage checkpoints: from initiation to recovery or adaptation. Curr Opin Cell Biol 2007;19(2):23845.

32. Reinhardt HC, Aslanian AS, Lees JA, Yaffe MB. p53-deficient cells rely on ATM- and ATR-mediated checkpoint signaling through the p38MAPK/MK2 pathway for survival after DNA damage. Cancer Cell 2007;11(2):175-89.

33. He L, Nan MH, Oh HC, Kim YH, Jang JH, Erikson RL, et al. Asperlin induces $\mathrm{G}_{2} / \mathrm{M}$ arrest through ROS generation and ATM pathway in human cervical carcinoma cells. Biochem Biophys Res Commun 2011;409(3):489-93. 
34. Agostinelli E, Seiler N. Non-irradiation-derived reactive oxygen species (ROS) and cancer: therapeutic implications. Amino Acids 2006;31(3):341-55.

35. Dröge W. Free radicals in the physiological control of cell function. Physiol Rev 2002;82(1):47-95.

36. Naidu MS, Suryakar AN, Swami SC, Katkam RV, Kumbar KM. Oxidative stress and antioxidant status in cervical cancer patients. Indian J Clin Biochem 2007;22(2):140-4.

37. Simon HU, Haj-Yehia A, Levi-Schaffer F. Role of reactive oxygen species (ROS) in apoptosis induction. Apoptosis 2000;5(5):415-8.

38. Wang Q, Zheng XL, Yang L, Shi F, Gao LB, Zhong YJ, et al. Reactive oxygen species-mediated apoptosis contributes to chemosensitization effect of saikosaponins on cisplatininduced cytotoxicity in cancer cells. J Exp Clin Cancer Res 2010;29:159.

39. Allouche Y, Warleta F, Campos M, Sánchez-Quesada C, Uceda M, Beltrán G, et al. Antioxidant, antiproliferative, and proapoptotic capacities of pentacyclic triterpenes found in the skin of olives on MCF-7 human breast cancer cells and their effects on DNA damage. J Agric Food Chem 2011;59(1):121-130.

40. Byun JY, Kim MJ, Eum DY, Yoon CH, Seo WD, Park KH, et al. Reactive oxygen species-dependent activation of Bax and poly(ADP-ribose) polymerase-1 is required for mitochondrial cell death induced by triterpenoid pristimerin in human cervical cancer cells. Mol Pharmacol 2009;76(4):734-44.

41. Wagner EF, Nebreda AR. Signal integration by JNK and p38 MAPK pathways in cancer development. Nat Rev Cancer 2009;9(8):537-49.

42. Ichijo H, Nishida E, Irie K, ten Dijke P, Saitoh M, Moriguchi T, et al. Induction of apoptosis by ASK1, a mammalian MAPKKK that activates SAPK/JNK and p38 signaling pathways. Science 1997;275(5296):90-4.

43. Waris G, Ahsan H. Reactive oxygen species: role in the development of cancer and various chronic conditions. J Carcinog 2006;5:14.

44. Fleury C, Mignotte B, Vayssière JL. Mitochondrial reactive oxygen species in cell death signaling. Biochimie 2002;84(23):131-141.
45. Laszczyk MN. Pentacyclic triterpenes of the lupane, oleanane and ursane group as tools in cancer therapy. Planta Med 2009;75(15):1549-60.

46. Rabi T, Bishayee A. Terpenoids and breast cancer chemoprevention. Breast Cancer Res Treat 2009;115(2):22339.

47. Liby KT, Yore MM, Sporn MB. Triterpenoids and rexinoids as multifunctional agents for the prevention and treatment of cancer. Nat Rev Cancer 2007;7(5):357-69.

48. Juan ME, Planas JM, Ruiz-Gutierrez V, Daniel H, Wenzel U. Antiproliferative and apoptosis-inducing effects of maslinic and oleanolic acids, two pentacyclic triterpenes from olives, on HT-29 colon cancer cells. Br J Nutr 2008;100(1):36-43.

49. Thoennissen NH, Iwanski GB, Doan NB, Okamoto R, Lin P, Abbassi $\mathrm{S}$, et al. Cucurbitacin $\mathrm{B}$ induces apoptosis by inhibition of the JAK/STAT pathway and potentiates antiproliferative effects of gemcitabine on pancreatic cancer cells. Cancer Res 2009;69(14):5876-84.

50. Martín R, Ibeas E, Carvalho-Tavares J, Hernández M, RuizGutierrez V, Nieto ML. Natural triterpenic diols promote apoptosis in astrocytoma cells through ROS-mediated mitochondrial depolarization and JNK activation. PLoS One 2009;4(6):e5975.

51. Liu T, Wang G, Tao H, Yang Z, Wang Y, Meng Z, et al. Capsaicin mediates caspases activation and induces apoptosis through P38 and JNK MAPK pathways in human renal carcinoma. BMC Cancer 2016;16(1):790.

52. Ruvolo PP, Deng X, May WS. Phosphorylation of Bcl2 and regulation of apoptosis. Leukemia 2001;15(4):515-22.

53. Torcia M, De Chiara G, Nencioni L, Ammendola S, Labardi $\mathrm{D}$, Lucibello $\mathrm{M}$, et al. Nerve growth factor inhibits apoptosis in memory B lymphocytes via inactivation of p38 MAPK, prevention of Bcl-2 phosphorylation, and cytochrome c release. J Biol Chem 2001;276(42):39027-36.

54. Haldar S, Chintapalli J, Croce CM. Taxol induces bcl-2 phosphorylation and death of prostate cancer cells. Cancer Res 1996;56(6):1253-5. 